\title{
Estimation of cation-exchange capacity in routine soil testing
}

\author{
RAINA NISKANEN and ANTTI JAAKKOLA \\ University of Helsinki, Department of Agricultural Chemistry \\ SF-00710 Helsinki, Finland
}

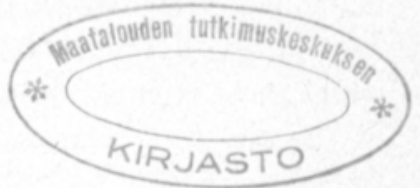

\begin{abstract}
The efficiency of the soil testing method used in Finland for predicting the effective cation-exchange capacity was studied in a material of 430 topsoil samples. The effective cationexchange capacity was estimated 1) by summation of exchangeable $\mathrm{Ca}, \mathrm{Mg}$ and acidity displaced by unbuffered $1 \mathrm{M} \mathrm{KCl}$ and 2) by summation of exchangeable $\mathrm{Ca}, \mathrm{Mg}, \mathrm{K}$ and $\mathrm{Na}$ displaced by neutral $1 \mathrm{M}$ ammonium acetate and exchangeable acidity. In soil testing, $\mathrm{Ca}, \mathrm{Mg}$ and $\mathrm{K}$ were extracted by acid ammonium acetate and soil $\mathrm{pH}$ measured in water-suspension.

The estimates of the effective CEC were highly correlated and dependent on the clay and organic carbon content and $\mathrm{pH}\left(\mathrm{CaCl}_{2}\right)$ of the soil, the coefficient of multiple determination being over $80 \%$. Exchangeable $\mathrm{Ca}$ was the dominating cation. The proportion of $\mathrm{Ca}$ of the effective CEC was about $80 \%$.

Acid ammonium acetate-extractable Ca together with pH( $\left.\mathrm{H}_{2} \mathrm{O}\right)$ explained over $80 \%$ of the variation in the effective CEC. For the whole material consisting of mineral soils with great variations in texture, organic carbon content and properties under evaluation, the regression equation predicting the effective CEC $\left(\mathrm{KCl}\right.$ method) was $\mathrm{CEC}(\mathrm{mval} / \mathrm{kg})=309-56.8 \mathrm{pH}\left(\mathrm{H}_{2} \mathrm{O}\right)+$ $0.085 \mathrm{Ca}(\mathrm{mg} / \mathrm{l})$. Only $16 \%$ of the estimates of the effective CEC calculated with this regression equation deviated more than $15 \%$ from the measured values.
\end{abstract}

Index words: exchangeable $\mathrm{Ca}, \mathrm{Mg}, \mathrm{K}, \mathrm{Na}$, exchangeable acidity, effective cation-exchange capacity, soil pH, soil testing

\section{Introduction}

In Finnish soil testing, lime requirement has been estimated on the basis of $\mathrm{pH}\left(\mathrm{H}_{2} \mathrm{O}\right)$ and acid ammonium acetate-extractable $\mathrm{Ca}$. According to MänTYLAHTI and Yläranta (1980), however, soil $\mathrm{pH}$ alone gives a better estimate. The content of extractable $\mathrm{Ca}$ in soil cannot be used as an index of liming requirements as long as the cation-exchange capacity and base saturation vary. On the other hand, exchangeable calcium contents together with acidity could estimate cation-exchange capacity of soil. The aim of this study was to examine the relationship between estimates of effective cation-exchange capacity of mineral soils and the possibility of predicting them by soil testing. 


\section{Material and methods}

The material consisted of 430 plough layer $(0-25 \mathrm{~cm})$ samples from the agricultural area of the Viikki Experimental Farm. The soil characteristics have been described previously by JOKINEN $(1983,1984)$ and NISKANEN and JAAKKOLA (1985). The samples were air-dried and ground to pass a 2-mm sieve. On the basis of the particle-size distribution determined by the pipette method (ELONEN 1971), the material consisted of 230 clay soils with a clay content $\geq 30 \%$ and 200 coarser soil samples with a clay content $<30 \%$ (Table 1$)$. The $\mathrm{pH}$ of the soil was measured in a soil-0.01 M $\mathrm{CaCl}_{2}$ suspension (1:2.5) (RyTI 1965). The mean $\mathrm{pH}$ of the coarser soils was $0.3 \mathrm{pH}$ units higher than that of clay soils (Table 1). The organic carbon content of the soil determined by a modified (Graham 1948) Alten's wet combustion method was on the average $1.5 \%$ higher in clay soils (Table 1).

Exchangeable $\mathrm{Ca}$ and $\mathrm{Mg}$ were extracted from $10 \mathrm{~g}$ soil by four successive treatments with $50 \mathrm{ml}$ of neutral $1 \mathrm{M}$ ammonium acetate and $50 \mathrm{ml} 1 \mathrm{M} \mathrm{KCl}$ and determined by atomic absorption spectrophotometry. Exchangeable $\mathrm{K}$ and $\mathrm{Na}$ were extracted with neutral 1 M ammonium acetate and determined by flame photometry.

The exchangeable acidity was displaced with $1 \mathrm{M} \mathrm{KCl}$ and titrated with $0.01 \mathrm{M} \mathrm{NaOH}$ (YUAN 1959). Two estimates for the effective cation-exchange capacity (CEC) were determined according to KAILA (1971 a, 1972). The effective CEC1 was estimated by summation of exchangeable $\mathrm{Ca}, \mathrm{Mg}$ and acidity displaced by $1 \mathrm{M} \mathrm{KCl}$. The effective CEC2 was estimated by summation of exchangeable $\mathrm{Ca}$, $\mathrm{Mg}$, Na and $\mathrm{K}$ extracted by neutral $1 \mathrm{M}$ ammonium acetate with exchangeable acidity displaced by unbuffered $1 \mathrm{M} \mathrm{KCl}$. The $\mathrm{pH}$ of the soil- $\mathrm{H}_{2} \mathrm{O}$ suspension $(1: 2.5 \mathrm{v} / \mathrm{v})$ and $\mathrm{Ca}$, $\mathrm{Mg}$ and $\mathrm{K}$ extracted with acid ammonium acetate $(0.5 \mathrm{M}$ acetic acid, $0.5 \mathrm{M}$ ammonium acetate, $\mathrm{pH} 4.65$, ratio $1: 10 \mathrm{v} / \mathrm{v}$ ) (VUORINEN and MÄKITIE 1955) were determined at a commer- cial soil testing laboratory (Viljavuuspalvelu Oy).

\section{Results}

The effective CEC1 averaged $150 \mathrm{mval} / \mathrm{kg}$ soil in clay soils (range $74-250 \mathrm{mval} / \mathrm{kg}$ soil) and $108 \mathrm{mval} / \mathrm{kg}$ soil in coarser soils (range 43-288 mval/ $\mathrm{kg}$ soil) (Table 1). On the average, more than $80 \%$ of the effective $\mathrm{CEC1}$ was saturated with exchangeable $\mathrm{Ca}$, $10 \%$ with exchangeable $\mathrm{Mg}$ and less than $10 \%$ with exchangeable acidity (Table 2).

Exchangeable $\mathrm{Ca}$ was rather closely correlated with calcium extracted by the routine soil-testing method $\left(\mathrm{r}=0.74^{* * *}\right)$. So was exchangeable magnesium with extractable magnesium $\left(\mathrm{r}=0.83^{* * *}\right)$. The variation in the sum of $\mathrm{KCl}$-extractable calcium and magnesium was fairly well explained by acid ammonium acetate-extractable calcium $\left(\mathrm{R}^{2}=\right.$ $0.66, \mathrm{n}=430$ ).

The relationship between exchangeable acidity and soil $\mathrm{pH}$ was curvilinear, but the logarithmic values of exchangeable acidity were lineariy correlated with soil $\mathrm{pH}$. With $\mathrm{pH}\left(\mathrm{H}_{2} \mathrm{O}\right)$ as an independent variable, the regression equation for the whole material $(\mathrm{n}=$ 430) was $\log$ (acidity) $=4.66-0.68 \mathrm{pH}\left(\mathrm{H}_{2} \mathrm{O}\right)$, $\mathrm{R}^{2}=0.83$.

The dependence of the effective CEC1 on soil properties was studied using clay and silt content $(\%)$, organic carbon content $(\%)$ and $\mathrm{pH}\left(\mathrm{CaCl}_{2}\right)$ as independent variables in the regression analysis. Clay content, organic carbon content and $\mathrm{pH}\left(\mathrm{CaCl}_{2}\right)$ together explained $83.4 \%$ of the variation in the effective CEC1 of the whole material, the regression equation being CEC1 (mval $/ \mathrm{kg})=$ $-227+1.85$ clay- $\%+45.6 \mathrm{pH}+11.2$ org.C $\%$. The silt content was an insignificant explainer. The content of clay fraction explained $67.5 \%$, organic carbon content $62.9 \%$ and $\mathrm{pH}\left(\mathrm{CaCl}_{2}\right) 65.4 \%$ of the variation in the effective CEC1, when the effect of the other two independent variables was eliminated.

The sum of exchangeable cations extracted by neutral $1 \mathrm{M}$ ammonium acetate averaged 
$161 \mathrm{mval} / \mathrm{kg}$ soil in clay soils (range 55$303 \mathrm{mval} / \mathrm{kg}$ soil) and $125 \mathrm{mval} / \mathrm{kg}$ soil in coarser soils (range 49-329 mval/ $\mathrm{kg}$ soil) (Table 1). The effective CEC2 estimated by summation of exchangeable acidity displaced by unbuffered $1 \mathrm{M} \mathrm{KCl}$ and exchangeable cations extracted by neutral $1 \mathrm{M}$ ammonium acetate averaged $172 \mathrm{mval} / \mathrm{kg}$ soil in clay soils (range 94-305 mval $/ \mathrm{kg}$ soil) and $129 \mathrm{mval} / \mathrm{kg}$ soil in coarser soils (range $55-333 \mathrm{mval} / \mathrm{kg}$ soil).
On the average, $75 \%$ of the effective CEC2 was saturated with exchangeable $\mathrm{Ca}$ in clay soils (range $21-92 \%$ ) and $81 \%$ in coarser soils (range 43-93\%). The proportion of $\mathrm{Mg}, \mathrm{K}$ and $\mathrm{Na}$ in the saturation of the effective CEC2 was only slightly higher in clay soils than in coarser soils. In the whole material, on the average $10 \%$ of the effective CEC2 was saturated with $\mathrm{Mg}$ (range 3-34\%), $5.3 \%$ with $\mathrm{K}$ (range $0.6-22 \%$ ) and $1.2 \%$ with $\mathrm{Na}$ (range $0.4-8.5 \%$ ). The proportion

Table 1. Soil characteristics.

\begin{tabular}{|c|c|c|c|c|c|c|c|c|c|}
\hline & \multicolumn{3}{|c|}{$\begin{array}{l}\text { All soils } \\
(n=430)\end{array}$} & \multicolumn{3}{|c|}{$\begin{array}{l}\text { Clay soils } \\
(\mathrm{n}=230)\end{array}$} & \multicolumn{3}{|c|}{$\begin{array}{l}\text { Coarser soils } \\
(\mathrm{n}=200)\end{array}$} \\
\hline & $\overline{\mathbf{x}}$ & $\mathbf{s}$ & range & $\overline{\mathbf{x}}$ & $\mathbf{s}$ & range & $\overline{\mathbf{x}}$ & $\mathbf{s}$ & range \\
\hline $\mathrm{pH}\left(\mathrm{CaCl}_{2}\right)$ & 5.3 & 0.6 & $4.0-6.8$ & 5.2 & 0.6 & $4.0-6.8$ & 5.5 & 0.5 & $4.5-6.8$ \\
\hline $\mathrm{pH}\left(\mathrm{H}_{2} \mathrm{O}\right)$ & 5.8 & 0.5 & $4.2-7.1$ & 5.7 & 0.5 & $4.2-7.1$ & 6.0 & 0.5 & $4.8-7.1$ \\
\hline Org.C, $\%$ & 5.2 & 2.2 & $1.8-14.6$ & 5.9 & 2.2 & $2.5-14.4$ & 4.4 & 2.0 & $1.8-14.6$ \\
\hline $\begin{array}{l}\text { Clay }(<0.002 \mathrm{~mm}), \% \\
\text { Silt }(0.002-\end{array}$ & 31 & 3 & $6-65$ & 41 & 6 & $30-65$ & 19 & 6 & $6-30$ \\
\hline $0.02 \mathrm{~mm}), \%$ & 17 & 8 & $3-43$ & 22 & 7 & $9-43$ & 13 & 6 & $3-37$ \\
\hline $\begin{array}{l}\text { Coarser fractions } \\
(0.02-2 \mathrm{~mm}), \%\end{array}$ & 52 & 18 & $20-91$ & 38 & 9 & $20-59$ & 69 & 10 & $40-91$ \\
\hline \multicolumn{10}{|c|}{ Exchangeable cations (mval/kg soil) extracted by $1 \mathrm{M} \mathrm{KCl}$ : } \\
\hline $\mathrm{Ca}$ & 109 & 36 & $0-257$ & 122 & 35 & $27-237$ & 93 & 29 & $0-257$ \\
\hline $\mathrm{Mg}$ & 14 & 11 & $0-72$ & 17 & 13 & $4-72$ & 11 & 6 & $0-44$ \\
\hline Acidity & 8 & 10 & $1-82$ & 11 & 11 & $1-66$ & 5 & 7 & $1-82$ \\
\hline $\begin{array}{l}\text { Sum of cations = } \\
\text { Effective CEC1 }\end{array}$ & 131 & 38 & $43-288$ & 150 & 33 & $74-250$ & 108 & 30 & $43-288$ \\
\hline \multicolumn{10}{|c|}{ Exchangeable cations (mval/ $\mathrm{kg}$ soil) extracted by neutral $1 \mathrm{M}$ ammonium acetate: } \\
\hline $\mathrm{Ca}$ & 119 & 39 & $25-292$ & 131 & 38 & $25-280$ & 105 & 35 & $38-292$ \\
\hline $\mathrm{Mg}$ & 16 & 12 & $3-79$ & 19 & 14 & $5-79$ & 12 & 5 & $3-31$ \\
\hline K & 8 & 4 & $1-37$ & 9 & 4 & $3-37$ & 6 & 3 & $1-21$ \\
\hline $\mathrm{Na}$ & 1.8 & 1.9 & $0.4-18.7$ & 2.3 & 2.4 & $0.6-18.7$ & 1.3 & 0.6 & $0.4-5.5$ \\
\hline Sum of cations & 144 & 45 & $49-329$ & 161 & 43 & $55-303$ & 125 & 38 & $49-329$ \\
\hline Effective CEC2 & & & & & & & & & \\
\hline $\mathrm{mval} / \mathrm{kg}$ soil & 152 & 43 & $55-333$ & 172 & 36 & $94-305$ & 129 & 37 & $55-333$ \\
\hline \multicolumn{10}{|c|}{ Cations (mval/l soil) extracted by acid ammonium acetate: } \\
\hline $\mathrm{Ca}$ & 89 & 28 & $14-193$ & 93 & 31 & $14-185$ & 85 & 24 & $35-193$ \\
\hline $\mathrm{Mg}$ & 14 & 13 & $2-154$ & 16 & 15 & $3-79$ & 11 & 11 & $2-154$ \\
\hline K & 6 & 3 & $1-32$ & 6 & 3 & $2-32$ & 5 & 2 & $1-16$ \\
\hline Sum of cations & 108 & 37 & $27-274$ & 115 & 42 & $27-224$ & 101 & 30 & $42-274$ \\
\hline
\end{tabular}

Table 2. Exchangeable cations extracted by $1 \mathrm{M} \mathrm{KCl}, \%$ of effective CEC1.

\begin{tabular}{|c|c|c|c|c|c|c|c|c|c|}
\hline & \multicolumn{3}{|c|}{$\begin{array}{l}\text { All soils } \\
(n=430)\end{array}$} & \multicolumn{3}{|c|}{$\begin{array}{l}\text { Clay soils } \\
(\mathrm{n}=230)\end{array}$} & \multicolumn{3}{|c|}{$\begin{array}{l}\text { Coarser soils } \\
(\mathrm{n}=200)\end{array}$} \\
\hline & $\bar{x}$ & $\mathbf{s}$ & range & $\bar{x}$ & s & range & $\overline{\mathrm{x}}$ & $\mathbf{s}$ & range \\
\hline $\mathrm{Ca}$ & 83 & 10 & $0-94$ & 80 & 10 & $26-94$ & 85 & 9 & $0-95$ \\
\hline $\mathrm{Mg}$ & 10 & 7 & $0-54$ & 11 & 7 & $3-37$ & 10 & 6 & $0-54$ \\
\hline Acidity & 7 & 9 & $0.4-100$ & 9 & 10 & $0.4-63$ & 5 & 8 & $0.6-100$ \\
\hline
\end{tabular}


of exchangeable acidity averaged $7.5 \%$ in clay soils (range $0.3-55 \%$ ) and $3.9 \%$ in coarser soils (range $0.5-52 \%$ ).

Clay content, organic carbon content and $\mathrm{pH}\left(\mathrm{CaCl}_{2}\right)$ together explained $84.4 \%$ of the variation in the effective $\mathrm{CEC} 2$, the regression equation being CEC2 $(\mathrm{mval} / \mathrm{kg})=-296+$ 1.97 clay- $\%+60.6 \mathrm{pH}+12.5$ org.C- $\%$. The clay content explained $66.6 \%, \mathrm{pH}\left(\mathrm{CaCl}_{2}\right)$ $73.8 \%$ and organic carbon content $64.1 \%$ of the variation in the effective CEC2, when the effect of the other two independent variables was eliminated.

The values of the effective CEC1 were about $85 \%$ of the effective CEC2 (Table 1), because exchangeable $\mathrm{K}$ and $\mathrm{Na}$ were not included in the CEC1, and more $\mathrm{Ca}$ was extracted with neutral ammonium acetate than with $\mathrm{KCl}$. The effective CEC1 and CEC2 were highly correlated $\left(\mathrm{r}=0.96^{* * *}, \mathrm{n}=430\right)$.

The sum of $\mathrm{Ca}, \mathrm{Mg}$ and $\mathrm{K}$ extracted by acid ammonium acetate averaged $115 \mathrm{mval} / 1$ soil in clay soils (range $27-224 \mathrm{mval} / 1$ soil) and $101 \mathrm{mval} / 1$ soil in coarser soils (range 42$274 \mathrm{mval} / 1$ soil) (Table 1). In the whole material, $83 \%$ of the cation sum, on the average, was saturated with $\mathrm{Ca}$ (range $41-94 \%$ ). The proportion of $\mathrm{Mg}$ averaged $11 \%$ (range $4-56 \%$ ) and that of $\mathrm{K} 6 \%$ (range 1$27 \%$ ). Clay and silt content, organic carbon content and $\mathrm{pH}\left(\mathrm{CaCl}_{2}\right)$ explained $86.8 \%$ of the cation sum, the regression equation being cation sum $(\mathrm{mval} / \mathrm{l})=-264+1.76$ clay$\%-1.03$ silt $-\%+60.2 \mathrm{pH}+3.11$ org.C- $\%$. The content of clay fraction explained $65.6 \%$, silt content $19.0 \%, \mathrm{pH}\left(\mathrm{CaCl}_{2}\right)$ $80 \%$ and organic carbon content $14.3 \%$ of the variation in the cation sum, when the effect of the other three independent variables was eliminated. The sum of cations extracted with acid ammonium acetate was not very closely correlated with the estimates of effective CEC. The correlation coefficient with CEC1 was $r=0.65^{* * *}(n=430)$.

The usability of $\mathrm{pH}\left(\mathrm{H}_{2} \mathrm{O}\right)$ and $\mathrm{Ca}, \mathrm{Mg}$ and $\mathrm{K}$ extracted by acid ammonium acetate in predicting the effective CEC was tested with clay soils, coarser soils and the whole material. The sum of $\mathrm{Ca}, \mathrm{Mg}$ and $\mathrm{K}$ together with $\mathrm{pH}\left(\mathrm{H}_{2} \mathrm{O}\right)$ explained the variation in the effective CEC as follows:

$\begin{array}{lccc} & \begin{array}{c}\text { clay } \\ \text { soils }\end{array} & \begin{array}{c}\text { coarser } \\ \text { soils }\end{array} & \begin{array}{c}\text { all } \\ \text { soils }\end{array} \\ \text { effective CEC1 } & 63.0 \% & 63.2 \% & 72.3 \% \\ \text { effective CEC2 } & 68.4 \% & 68.9 \% & 74.1 \%\end{array}$

The coefficients of determination slightly increased when $\mathrm{K}$ was omitted from the sum of cations. The sum of $\mathrm{Ca}$ and $\mathrm{Mg}$ together with $\mathrm{pH}\left(\mathrm{H}_{2} \mathrm{O}\right)$ explained the variation in the effective CEC as follows:

$\begin{array}{cccc} & \begin{array}{c}\text { clay } \\ \text { soils }\end{array} & \begin{array}{c}\text { coarser } \\ \text { soils }\end{array} & \begin{array}{c}\text { all } \\ \text { soils }\end{array} \\ \text { effective CEC1 } & 69.3 \% & 65.0 \% & 74.8 \% \\ \text { effective CEC2 } & 71.5 \% & 70.0 \% & 75.3 \%\end{array}$

The highest values of the coefficient of determination were obtained by using acid ammonium acetate-extractable $\mathrm{Ca}$ instead of cation sum as an independent variable. With $\mathrm{Ca}$ and $\mathrm{pH}\left(\mathrm{H}_{2} \mathrm{O}\right)$ as independent variables explaining the variation in the effective $\mathrm{CEC1}$, the coefficients of determination and corresponding regression equations were as follows:

$$
\begin{array}{lll}
\text { clay soils } & 81.6 \% & \mathrm{CEC} 1(\mathrm{mval} / \mathrm{kg})=274-47.6 \mathrm{pH}+1.58 \mathrm{Ca}(\mathrm{mval} / \mathrm{l}) \\
\text { coarser soils } & 75.8 \% & \mathrm{CECl}(\mathrm{mval} / \mathrm{kg})=251-44.2 \mathrm{pH}+1.43 \mathrm{Ca}(\mathrm{mval} / \mathrm{l}) \\
\text { all soils } & 82.6 \% & \mathrm{CECl}(\mathrm{mval} / \mathrm{kg})=309-56.8 \mathrm{pH}+1.70 \mathrm{Ca}(\mathrm{mval} / \mathrm{l})
\end{array}
$$

With the effective CEC2 as a dependent variable, the coefficients of determination and corresponding regression equations were as follows:

$\begin{array}{lll}\text { clay soils } & 80.4 \% & \mathrm{CEC} 2(\mathrm{mval} / \mathrm{kg})=242-38.4 \mathrm{pH}+1.59 \mathrm{Ca}(\mathrm{mval} / \mathrm{l}) \\ \text { coarser soils } & 84.5 \% & \mathrm{CEC} 2(\mathrm{mval} / \mathrm{kg})=223-41.2 \mathrm{pH}+1.79 \mathrm{Ca}(\mathrm{mval} / \mathrm{l}) \\ \text { all soils } & 84.0 \% & \mathrm{CEC} 2(\mathrm{mval} / \mathrm{kg})=292-52.9 \mathrm{pH}+1.88 \mathrm{Ca}(\mathrm{mval} / \mathrm{l})\end{array}$


The partial correlation coefficients for the relation between the effective $\mathrm{CECl}$ (1) or
CEC2 (2), pH( $\left.\mathrm{H}_{2} \mathrm{O}\right)(3)$ and acid ammonium acetate-extractable $\mathrm{Ca}(4)$ were as follows:

$\begin{array}{lllll} & \mathrm{r}_{13.4} & \mathrm{r}_{14.3} & \mathrm{r}_{23.4} & \mathrm{r}_{24.3} \\ \text { clay soils } & -0.69^{* * *} & 0.88^{* * *} & -0.56^{* * *} & 0.84^{* * *} \\ \text { coarser soils } & -0.72^{* * *} & 0.87^{* * *} & -0.70^{* * *} & 0.92^{* * *} \\ \text { all soils } & -0.81^{* * *} & 0.91 * * * & -0.76^{* * *} & 0.91^{* * *}\end{array}$

Omitting $\mathrm{pH}\left(\mathrm{H}_{2} \mathrm{O}\right)$ from the regression analysis decreased the coefficient of determination considerably. With acid ammonium acetate-extractable $\mathrm{Ca}$ as the only independent variable, $50.2 \%$ of the variation in the effective CEC1 for the whole material was explained.

Theoretically it was justified to test the relationship between effective CEC, $\mathrm{pH}\left(\mathrm{H}_{2} \mathrm{O}\right)$ and acid ammonium acetate-extractable $\mathrm{Ca}$ also with a regression model in which all variables were logarithmic. However, this model was not superior to the model tested before. According to the logarithmic model, the relationship between the effective CEC1, $\mathrm{pH}\left(\mathrm{H}_{2} \mathrm{O}\right)$ and $\mathrm{Ca}$ in the whole material was described by the equation $\log \mathrm{CEC} 1=1.12+$ $1.08 \log \mathrm{Ca}-0.19 \mathrm{pH}, \mathrm{R}^{2}=0.75$.

The coefficients of determination for clay and coarser soil groups obtained with $\mathrm{Ca}$ and $\mathrm{pH}\left(\mathrm{H}_{2} \mathrm{O}\right)$ as independent variables did not deviate very much from each other. Therefore the examination of the material as a whole was appropriate. The variation in the estimates of the effective CEC was explained equally well. The measured values of the effective CEC1 were compared with the values calculated according to the regression equation $\mathrm{CECl}$ (mval/ $\mathrm{kg})=309-56.8 \mathrm{pH}+1.70 \mathrm{Ca}(\mathrm{mval} / \mathrm{l})$. The relationship between measured and predicted values is presented in Figures 1 and 2 . The proportion of samples with the predicted value deviating more than $15 \%$ from the measured value was $16 \%$ of the whole material. This proportion included $11 \%$ of the clay soil samples and $22.5 \%$ of the coarser soil samples. In clay soils, the deviation did not exceed $30 \%$ of the measured value. Coarser soil samples with the predicted value much below the measured value (No. 1-3) were

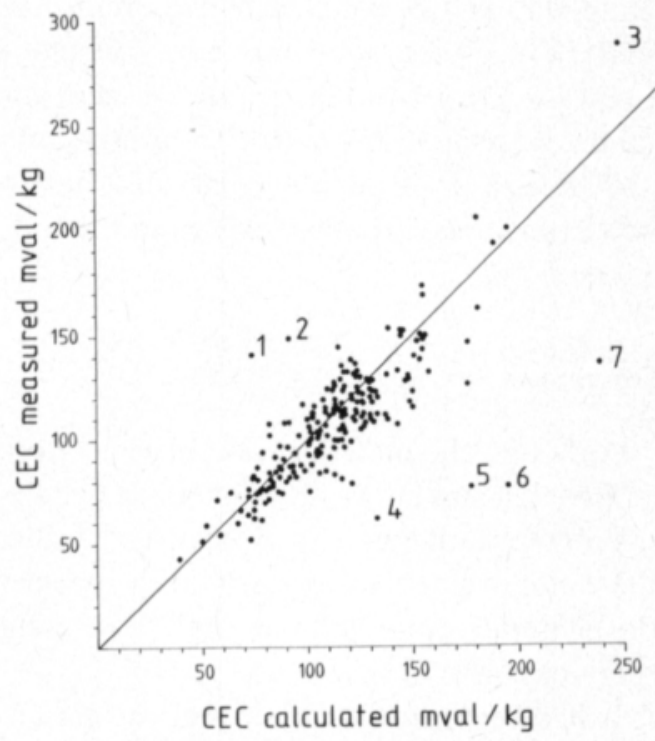

Fig. 1. Relationship between measured effective CEC1 $(\mathrm{Ca}+\mathrm{Mg}+$ acidity $)$ and its estimate calculated on the basis of soil testing data $(\mathrm{Ca}+\mathrm{pH})$ in coarse mineral soils.

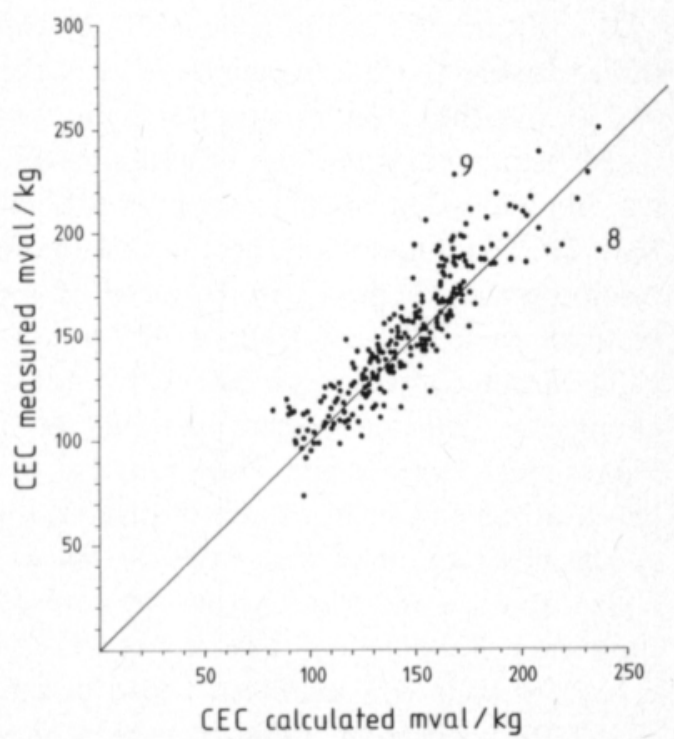

Fig. 2. Relationship between measured effective CEC1 $(\mathrm{Ca}+\mathrm{Mg}+$ acidity $)$ and its estimate calculated on the basis of soil testing data $(\mathrm{Ca}+\mathrm{pH})$ in clay soils. 
characterized by high clay and organic carbon content. In clay soils the sample with the greatest underestimation of the measured value (No. 9) was characterized by high organic carbon content. Samples with the predicted value much above the measured value (No. 4-8) were characterized by low or moderate clay and organic carbon content. The $\mathrm{pH}\left(\mathrm{H}_{2} \mathrm{O}\right)$ of these soils were $6.0-7.0$ and in two cases (No. 7-8) the content of acid ammonium acetate-extractable $\mathrm{Ca}$ was high, over $160 \mathrm{mval} / \mathrm{l}$. It is possible that some undissolved calcium carbonate existed in the soil.

\section{Discussion}

Although the material was collected from a restricted area, it was characterized by relatively great variations in soil properties. Under these circumstances it is justified to consider the material quite suitable for the present examination.

It has been shown earlier that the cationexchange capacity of Finnish mineral soils is largely dependent on clay and organic carbon content (Heinonen 1960, MartTila 1965, JOKINEN 1984) together with soil pH (KAILA $1971 \mathrm{a}, \mathrm{b})$. In the study of KaILA (1971 b), the three variables together explained $83 \%$ of the variation in the effective cation-exchange capacity estimated as the sum of exchangeable $\mathrm{Ca}, \mathrm{Mg}$ and acidity displaced by unbuffered $\mathrm{KCl}$. The result is in good agreement with the results obtained in this study. However, in the material $(n=230)$ of KAILA $(1971$ b), organic carbon content was a lesser explainer as compared with the present material with higher mean content and wider range of organic carbon and smaller range of $\mathrm{pH}\left(\mathrm{CaCl}_{2}\right)$.

The observation of KaILA (1972) that exchangeable $\mathrm{Ca}$ and $\mathrm{Mg}$ together saturate on the average $80-90 \%$ of the effective CEC of cultivated soils was manifested also in this study. The proportion of exchangeable acidity was of minor importance in most soils. The average ratio of exchangeable $\mathrm{Ca}$ to $\mathrm{Mg}$ was about 7 in clay soils and nearly 9 in coarser soils. In the study of KaILA (1972), the ratio in sand and fine sand soils was about 9 and in clay soils (clay- $\%<60$ ) about 4 . According to Schmid (1965), the ratio of $\mathrm{Ca}$ to $\mathrm{Mg}$ would be $5-8$ to 1 . The average ratio of exchangeable $\mathrm{Mg}$ to $\mathrm{K}$ was about 2 both in clay soils and in coarser soils. The average ratio of exchangeable $\mathrm{K}$ to $\mathrm{Na}$ was higher in coarser soils than in clay soils, the values being 4.6 and 3.9, respectively. In the study of KaILA (1972), the ratio of $\mathrm{Mg}$ to $\mathrm{K}$ was $2-8$ and the ratio of $\mathrm{K}$ to $\mathrm{Na} 2-2.8$.

On the basis of soil testing, the cationexchange capacity of soil was to some extent predictable. The variation in the effective $\mathrm{CEC}$ was best explained by $\mathrm{pH}$ in soil-water suspension and $\mathrm{Ca}$ extracted by acid ammonium acetate. Indeed, additional variation can be caused by the fact that cation-exchange capacity was expressed on a weight basis and acid ammonium acetate-extractable $\mathrm{Ca}$ on a volume basis. Using the sum of $\mathrm{Ca}$ and $\mathrm{Mg}$ or $\mathrm{Ca}, \mathrm{Mg}$ and $\mathrm{K}$ extracted by acid ammonium acetate instead of Ca did not increase the coefficient of determination. This was largely due to the fact that $\mathrm{K}$ and $\mathrm{Mg}$ were only minor components of CEC.

The effective CEC was adequately predictable by a regression equation in which $\mathrm{pH}\left(\mathrm{H}_{2} \mathrm{O}\right)$ and acid ammonium acetate-extractable $\mathrm{Ca}$ were independent variables. The same equation could be applied to all mineral soils. When $\mathrm{Ca}$ is expressed as $\mathrm{mg} / \mathrm{l}$, the equation takes the form CEC $(\mathrm{mval} / \mathrm{kg})=309-$ $56.8 \mathrm{pH}\left(\mathrm{H}_{2} \mathrm{O}\right)+0.085 \mathrm{Ca}(\mathrm{mg} / \mathrm{l})$. Most of the material was such that the predicted CEC value did not deviate more than $15 \%$ from the measured value. Some characteristics common to the samples with a great deviation were observed. High content of organic carbon, e.g., seemed to be associated with a great underestimation of CEC. The immediate reason in this case might be the smaller bulk density which affects the relationship between values given on weight and volume basis. 


\section{References}

Elonen, P. 1971. Particle-size analysis of soil. Acta Agr. Fenn. 122: 1-122.

Graham, E. 1948. Determination of soil organic matter by means of a photoelectric colorimeter. Soil Sci. 65: $181-183$.

Heinonen, R. 1960. Über die Umtauschkapazităt des Bodens und verschiedenen Bodenbestandteile in Finnland. Z. Pflanzenern. Düng. Bodenk. 88: 49-59.

JOKINEN, R. 1983. Variability of topsoil properties at the southern coast of Finland and the number of soil samples needed for the estimation of soil properties. J. Scient. Agric. Soc. Finl. 55: 109-117.

,- 1984 . Comparison of and correlation between the characteristics of agricultural topsoil and subsoil at the southern coast of Finland. J. Agric. Sci. Finl. 56: $245-254$.

KAILA, A. 1971 a. Effective cation-exchange capacity in Finnish mineral soils. J. Scient. Agric. Soc. Finl. 43: $178-186$.

-, 1971 b. Über den Anteil organischer Substanz an der Austauschkapazităt von Mineralböden in Finnland. Spomenica uz 70. god. prof. Gračanina, Zagreb, p.
$53-56$

-, 1972. Basic exchangeable cations in Finnish mineral soils. J. Scient. Agric. Soc. Finl. 44: 164-170.

MartTILA, U. 1965. Exchangeable cations in Finnish soils. J. Scient. Agric. Soc. Finl. 37: 148-161.

MãntYlahtı, V. \& Yläranta, T. 1980. The estimation of soil lime requirement in soil testing. Ann. Agric. Fenn. 19: $92-99$.

Niskanen, R. \& JaAKKola, A. 1985. Comparison of analytical methods in testing soil fertility. J. Agric. Sci. Finl. 57: 183-194.

RYTI, R. 1965. On the determination of soil $\mathrm{pH}$. J. Scient. Agric. Soc. Finl. 37: 51-60.

ScнміD, G. 1965. Einfluss der Basensättigung auf die Bodenfruchtbarkeit. Landw. Forsch. 28: 97-107.

Vuorinen, J. \& Mä́ıтї, O. 1955. The method of soil testing in use in Finland. Agrogeol. Publ. 63: 1-44.

YUAN, T.L. 1959. Determination of exchangeable hydrogen in soils by a titration method. Soil Sci. 88: 164-167.

Ms received November 6, 1985

\section{SELOSTUS}

\section{Kationinvaihtokapasiteetin likiarvon laskeminen viljavuustutkimuksen perusteella}

\author{
Raina Niskanen ja Antti Jaakkola \\ Helsingin yliopisto, Maanviljelyskemian laitos, \\ $00710 \mathrm{Helsinki}$
}

Tutkimuksessa selviteltiin, voidaanko viljavuustutkimuksessa määritettävien happamaan ammoniumasetaattiin uuttuvien kalsiumin, magnesiumin ja kaliumin pitoisuuksien sekä maa-vesisuspensiosta määritetyn pH:n avulla laskea likiarvo maan efektiiviselle kationinvaihtokapasiteetille. Aineisto käsitti 430 kivennäismaiden muokkauskerroksesta otettua näytettä. Efektiivinen kationinvaihtokapasiteetti määritettiin $1 \mathrm{M}$ kaliumkloridilla vaihtuvan kalsiumin, magnesiumin ja happamuuden summana sekă vaihtuvan happamuuden ja neutraalilla $1 \mathrm{M}$ ammoniumasetaatilla uuttuvan kalsiumin, magnesiumin, kaliumin ja natriumin summana.

Molemmilla menetelmillă saadut efektiivisen kationinvaihtokapasiteetin arvot korreloivat voimakkaasti keskenäăn. Saveksen ja orgaanisen hiilen pitoisuus yhdessă
$\mathrm{pH}\left(\mathrm{CaCl}_{2}\right)$ :n kanssa selitti yli $80 \%$ efektiivisen kationinvaihtokapasiteetin vaihtelusta. Vaihtuvan kalsiumin keskimääräinen osuus efektiivisestă kationinvaihtokapasiteetista oli noin $80 \%$.

Happamalla ammoniumasetaatilla uuttuva kalsium yhdessä maa-vesisuspensiosta mitatun $\mathrm{pH}$ :n kanssa selitti yli $80 \%$ efektiivisen kationinvaihtokapasiteetin vaihtelusta. Koko maa-aineistolle voitiin käyttäă samaa regressioyhtäloä, joka $\mathrm{KCl}$-menetelmällä măăritetylle efektiiviselle kationinvaihtokapasiteetille oli seuraava: $\mathrm{KVK}(\mathrm{mval} / \mathrm{kg})=309-56.8 \mathrm{pH}\left(\mathrm{H}_{2} \mathrm{O}\right)+0.085 \mathrm{Ca}(\mathrm{mg} / \mathrm{l})$. Vain $16 \%$ năytteistă oli sellaisia, että regressioyhtälöstă laskettu KVK:n arvo poikkesi määritetystä arvosta enemmăn kuin $15 \%$. 